\title{
Thermal and evolved gas analyses of decomposition of ammonium dinitramide-based ionic liquid propellant using TG-DSC-HRTOFMS.
}

\author{
Yu-ichiro Izato \\ Graduate school of Environment and Information Sciences, Yokohama National \\ University, 79-7 Tokiwadai, Hodogaya-ku, Yokohama, Kanagawa 240-8501, Japan \\ Phone: +81-45-339-3992 \\ E-mail: izato-yuichiro-hk@ynu.jp
}

Kento Shiota

Institute of Advanced Sciences, Yokohama National University, 79-5, Tokiwadai, Hodogaya-ku, Yokohama, Kanagawa 240-8501, Japan

Kenta Satoh

Application group, NETZSCH Japan K.K., 3-9-13, Moriya-cho, Kanagawa-ku, Yokohama, Kanagawa 221-0022, Japan

Takashi Satoh

MS Research and Development Department, MS Business Unit, JEOL Ltd., 3-1-2 Musashino, Akishima, Tokyo 196-8558, Japan

Yukinori Yahata

MS Research and Development Department, MS Business Unit, JEOL Ltd., 3-1-2 Musashino, Akishima, Tokyo 196-8558, Japan

Hiroto Habu

Division for Space Flight Systems, Institute of Space and Astronautical Science (ISAS), Japan Aerospace Exploration Agency (JAXA), 3-1-1, Yoshinodai, Chuo-ku, Sagamihara, Kanagawa 252-5210, Japan

Atsumi Miyake

Institute of Advanced Sciences, Yokohama National University, 79-5, Tokiwadai, Hodogaya-ku, Yokohama, Kanagawa 240-8501, Japan

Abstract Thermal and evolved gas analyses were carried out to assess the decomposition of an ionic liquid propellant consisting of ammonium dinitramide (ADN), methylammonium nitrate (MMAN) and urea, using thermogravimetry-differential scanning calorimetry-high resolution time of flight mass spectrometry (TG-DSC-HRTOFMS). This technique simultaneously assesses the thermal and evolved gas behavior and is able to distinguish between products having similar massto-charge ratios, based on accurate mass determinations. ADN/MMAN and ADN/MMAN/urea mixtures were found to decompose to form $\mathrm{NH}_{3}, \mathrm{H}_{2} \mathrm{O}, \mathrm{HCN}, \mathrm{CO}, \mathrm{N}_{2}, \mathrm{CH}_{2} \mathrm{O}, \mathrm{CH}_{3} \mathrm{NH}_{2}, \mathrm{HNCO}$, $\mathrm{CO}_{2}, \mathrm{~N}_{2} \mathrm{O}$ and $\mathrm{HNO}_{3}$, and possible reaction schemes for the decomposition processes were developed. Interactions between ADN and MMAN appear to enhance the generation of $\mathrm{N}_{2}$, while the presence of urea reduces the net exothermic heat of reaction due to the endothermic pyrolysis reaction of urea to $\mathrm{NH}_{3}$ and $\mathrm{HNCO}$, followed by the reaction $\mathrm{HNCO}+\mathrm{H}_{2} \mathrm{O} \rightarrow \mathrm{NH}_{3}+\mathrm{CO}_{2}$.

Keywords ammonium dinitramide, ionic liquid propellant, thermal decomposition, evolved gas analysis, TG-DSC-HRTOFMS 


\section{Introduction}

Ammonium dinitramide (ADN) has attracted attention as a solid rocket propellant or liquid monopropellant oxidizer because it has both a high oxygen balance and significant energy content, but does not contain halogen atoms $[1,2,3]$. As an example, the novel ADN-based liquid monopropellants LMP-103S and FLP-106, consisting of blends of ADN, water, methanol and ammonia, were previously developed within a co-operative project between the Swedish Space Corporation and the Swedish Defense Research Agency [1, 4]. These formulations have been assessed as a means of improving performance during the European Union Horizon2020 RHEFORM project [4].

In general, the addition of water and other solvents to propellants reduces combustion performance and energy density while providing the low viscosity required for nozzle injection and the low melting point necessary to maintain the propellant in the liquid state without an external heater in outer space. Thus, it would be beneficial to develop solvent-free ADN-based liquid propellants. One possible approach to this goal is the use of ionic liquids, which are molten salts consisting entirely of ions, having melting points below $100{ }^{\circ} \mathrm{C}$ and potentially as low as room temperature. Ionic liquids containing ADN and other energetic salts could conceivably function as solvent-free, high-energy liquid propellants.

Our previous study [5] demonstrated the possibility of producing a room temperature ionic liquid based on a binary mixture of ADN and monomethylammonium nitrate (MMAN). This formulation exhibited a melting point of $3{ }^{\circ} \mathrm{C}$; far less than those of pure ADN $\left(93^{\circ} \mathrm{C}\right)$ and MMAN $\left(109^{\circ} \mathrm{C}\right)$. This prior work also found that the addition of amides, such as urea and acetamide, can depress the melting point of ADN [5] via the deep eutectic mechanism.

Matsunaga et al. [6-9] previously reported that ternary mixtures of ADN, MMAN and urea have very low melting points (below $-30^{\circ} \mathrm{C}$ ) and thus have potential as alternatives to hydrazine mono-propellants. Chemical equilibrium computations predict that the performance of these ADN-based propellants will also be superior to that of hydrazine. Ide et al. [10] investigated the combustion behavior of such mixtures using a strand burner and found that ADN-based propellants exhibit self-sustaining combustion in an inert atmosphere.

Understanding the decomposition and combustion reaction of propellants is useful when developing comprehensive ignition and combustion models for rocket motors that employ propellants. A sophisticated model incorporating elementary reactions and all associated chemical species can assist in predicting temporal changes in combustion characteristics, including reactant concentrations, products, temperatures, pressures and the rate determining step. Our goal is to develop such a model for ADN-based propellants. To this end, both of refined computational and experimental approaches are needed. More recently, computational studies have progressed to offer some reliable detailed reaction mechanisms for energetic materials obtained based on quantum mechanics methods [11-15].

There have been many experimental studies aimed at determining the reaction mechanisms associated with energetic materials. Thermal analysis with evolved gas analysis (TA-EGA) using TG-DSC (or DTA) together with MS and IR spectroscopy is a powerful tool for investigating the reaction mechanisms of energetic materials. TA-EGA elucidates the gas evolution behavior together with the thermal profile and thus offers significant insights into reaction mechanisms. Furthermore, MS data allow the identification of the molecular weights of evolved gases, while IR spectra show the chemical structures. For these reasons, TG-MS and TG-IR studies have been widely conducted to investigate the reaction mechanisms of various energetic materials, including ADN and its mixtures [16-31]. Matsunaga et al. [6, 7, 9] conducted a thermal analysis of ADN/MMAN/urea mixtures using differential scanning calorimetry (DSC), thermogravimetry-differential thermal analysis-infrared spectroscopy (TGDTA-IR) and mass spectrometry (MS) and demonstrated that these materials decompose to generate various gases, including nitrous oxide $\left(\mathrm{N}_{2} \mathrm{O}\right)$, nitrogen dioxide $\left(\mathrm{NO}_{2}\right)$, isocyanic aid ( $\mathrm{HNCO})$, ammonia $\left(\mathrm{NH}_{3}\right)$, carbon dioxide $\left(\mathrm{CO}_{2}\right)$ and water $\left(\mathrm{H}_{2} \mathrm{O}\right)$.

However, there are certain issues associated with using TG-MS and TG-IR for this purpose. It can be difficult to distinguish between different species having similar masses based on lowresolution MS data (for example, between $\mathrm{CO}_{2}$ (for which the molecular ion $\mathrm{m} / \mathrm{z}$ value is 44 [32]) and $\mathrm{N}_{2} \mathrm{O}\left(m / z 44\right.$ [32]), and between $\mathrm{CO}\left(m / z 28\right.$ [32]) and $\mathrm{N}_{2}(m / z 28$ [32])). These gases are typically the major species produced by the decomposition and combustion of energetic materials, and so it is important to understand their evolution and reaction mechanisms. 
Unfortunately, due to the trade-off relationship between resolution and response time, these compounds often cannot be distinguished during TG-MS studies. In contrast, IR analysis can distinguish between $\mathrm{CO}_{2}$ and $\mathrm{N}_{2} \mathrm{O}$ based on their different functional groups, but TG-IR analysis often does not allow quantitative analysis and may not detect species with low infrared activity.

The aim of the present study was to investigate the gases evolved from the decomposition of ionic liquid propellants made from ADN/MMAN or ADN/MMAN/urea mixtures, using TG and DSC in conjunction with high resolution time of flight MS (TG-DSC-HRTOFMS). HRTOFMS is a powerful instrumental technique for the analysis of complex gas mixtures and offers the advantages of rapid scanning and acquisition of the full mass spectra of the fragment ions of compounds on an accurate mass basis.

\section{Experimental}

The ADN and urea (purity $99 \%$ ) used in this work were obtained from the Hosoya PyroEngineering Co., Ltd., Japan, and from Wako Pure Chemical Industries, Ltd., Japan, respectively. MMAN was synthesized from an aqueous methylamine solution (40\%, Wako Pure Chemical Industries, Ltd., Japan) and nitric acid (60\%, Wako Pure Chemical Industries, Ltd., Japan). During this procedure, nitric acid $\left(\mathrm{HNO}_{3}\right)$ was added dropwise to the methylamine solution, cooled in ice water, until a $\mathrm{pH}$ of approximately 7 was obtained. All of excess water was subsequently removed from the resulting MMAN solution by heating in an evaporator under vacuum.

Ionic propellant samples were prepared by mixing the pure materials at an ADN:MMAN mass ratio of 1:1 or an ADN:MMAN:urea mass ratio of 2:2:1, working in a glove box at $20 \%$ relative humidity. The latter mixture had a particularly low melting point, such that it remained liquid at $0{ }^{\circ} \mathrm{C}$, and had a theoretical vacuum specific impulse of $293 \mathrm{~s}$ (much higher than that of present-day hydrazine-based monopropellants) [6]. These samples were subsequently heated in a constanttemperature oven at $60^{\circ} \mathrm{C}$ for $24 \mathrm{~h}$ and then held at approximately $15{ }^{\circ} \mathrm{C}$ at $20 \%$ relative humidity in accordance to the reference [5]. Both the binary and ternary mixtures melted based on the eutectic mechanism and were liquids at room temperature.

The TG-DSC-HRTOFMS apparatus consisted of an STA 449 F1 Jupiter thermogravimetric analyzer (Netsczh) and a JMS-MT3010HRGA INFITOF instrument (JEOL) equipped with an inline EGA accessory (Netsczh). Both thermal and MS data were acquired simultaneously to assess the thermal behavior of the liquid propellant samples and to identify the gases evolved upon heating. In each trial, an approximately $2.0 \mathrm{mg}$ (ADN/MMAN) or $5.0 \mathrm{mg}$ (ADN/MMAN/urea) sample was placed in an aluminum pan $(\varnothing 5 \mathrm{~mm} \times 5 \mathrm{~mm})$ and heated from 30 to $350{ }^{\circ} \mathrm{C}$ at $10^{\circ} \mathrm{C} \mathrm{min}^{-1}$ under a continuous $100 \mathrm{~mL} \mathrm{~min}^{-1}$ helium purge. Prior to heating, the TG-DSC instrument was evacuated for $5 \mathrm{~min}$ and then filled with helium to a pressure of $1 \mathrm{~atm}$. An empty aluminum pan was used as a reference. After each trial, the sample was replaced with fresh material (number of trials was three for sample). The gaseous decomposition products were analyzed using the HRTOFMS connected to the TG-DSC apparatus by a heated quartz capillary $\left(300^{\circ} \mathrm{C}\right)$. The MS was performed in electron ionization mode $(70 \mathrm{eV})$, with scanning from $\mathrm{m} / \mathrm{z} 10$ to 100 .

\section{Results and discussions}

\section{ADN/MMAN}

Figure 1 shows the TG-DSC-HRTOFMS results for the ADN/MMAN mixture. The TG-DSC data (Figure 1(a)) demonstrate an exothermic event associated with a mass loss at approximately $130-210^{\circ} \mathrm{C}$, suggesting that the ADN/MMAN decomposed via an exothermic reaction with gas evolution. The heat release from this reaction was determined to be $1057 \pm$ $94 \mathrm{~J} \mathrm{~g}^{-1}$. Approximately $1 \%$ of the original mass remained at $350{ }^{\circ} \mathrm{C}$, indicating that the ADN/MMAN may have produced a small amount of solid residue. This material likely consisted of polymers derived from $\mathrm{HNCO}$, but further investigation is needed to conclusively identify the solid material. 


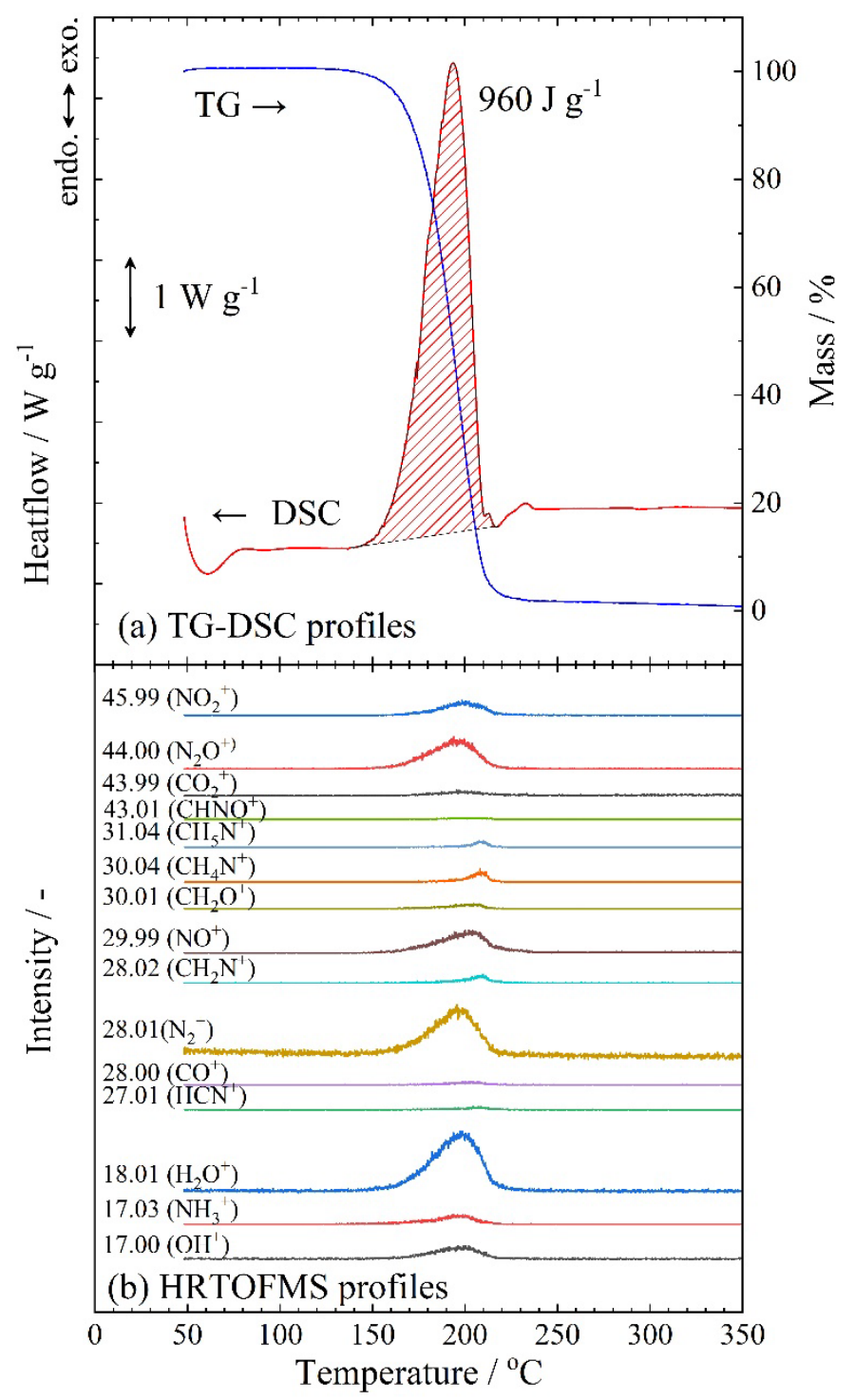

Figure 1. TG-DSC-HRTOFMS results for ADN/MMAN at a heating rate of $10 \mathrm{~K} \mathrm{~min}^{-1}$.

The MS data show peaks at $m / z$ values of $17.00\left(\mathrm{OH}^{+}\right), 17.03\left(\mathrm{NH}_{3}{ }^{+}\right), 18.01\left(\mathrm{H}_{2} \mathrm{O}^{+}\right), 27.01$ $\left(\mathrm{HCN}^{+}\right), 28.00\left(\mathrm{CO}^{+}\right), 28.01\left(\mathrm{~N}_{2}^{+}\right), 28.02\left(\mathrm{CH}_{2} \mathrm{~N}^{+}\right), 29.99\left(\mathrm{NO}^{+}\right), 30.01\left(\mathrm{CH}_{2} \mathrm{O}^{+}\right), 30.04$ $\left(\mathrm{CH}_{4} \mathrm{~N}^{+}\right), 31.04\left(\mathrm{CH}_{5} \mathrm{~N}^{+}\right), 43.99\left(\mathrm{CO}_{2}^{+}\right), 44.00\left(\mathrm{~N}_{2} \mathrm{O}^{+}\right)$and $45.99\left(\mathrm{NO}_{2}^{+}\right)$, and the variations in the peak intensities with temperature are shown in Figure 1(b). Data for additional minor species are provided in the Supplementary Materials. From these results, the primary evolved gases were determined to be $\mathrm{NH}_{3}\left(\mathrm{~m} / z\right.$ 17.03), $\mathrm{H}_{2} \mathrm{O}(\mathrm{m} / \mathrm{z} 18.01$ and 17.00), $\mathrm{HCN}(\mathrm{m} / z 27.01)$ $\mathrm{CO}(\mathrm{m} / \mathrm{z} 28.00), \mathrm{N}_{2}(\mathrm{~m} / \mathrm{z} 28.01), \mathrm{CH}_{2} \mathrm{O}\left(\mathrm{m} / z\right.$ 30.01), $\mathrm{CH}_{3} \mathrm{NH}_{2}(\mathrm{~m} / \mathrm{z} 31.04$ and 30.04$), \mathrm{CO}_{2}(\mathrm{~m} / \mathrm{z}$ 43.99 and 28.00) and $\mathrm{N}_{2} \mathrm{O}(\mathrm{m} / z$ 44.00, 29.99, and 28.01).

The peak at $m / z 45.99\left(\mathrm{NO}_{2}{ }^{+}\right)$can be attributed to $\mathrm{HNO}_{3}$, which, in low-resolution spectra, typically generates peaks at $\mathrm{m} / z$ values of $46\left(\mathrm{NO}_{2}{ }^{+}\right.$, relative intensity of approximately 100$)$, $30\left(\mathrm{NO}^{+}\right.$, relative intensity of 85.7), and $63\left(\mathrm{HNO}_{3}{ }^{+}\right.$, relative intensity of 2.5) [33]. In such spectra, $\mathrm{HNO}_{3}{ }^{+}\left(\mathrm{m} / z\right.$ 63) is not typically observed. ADN decomposition is known to yield $\mathrm{HNO}_{3}$, and the ADN and MMAN mixture would be expected to contain $\mathrm{NO}_{3}{ }^{-}, \mathrm{NH}_{4}{ }^{+}$and $\mathrm{CH}_{3} \mathrm{NH}_{3}{ }^{+}$. In this ionic liquid, the proton-transfer reactions $\mathrm{NH}_{4}{ }^{+}+\mathrm{NO}_{3}{ }^{-} \rightarrow \mathrm{NH}_{3}+\mathrm{HNO}_{3}$ and $\mathrm{CH}_{3} \mathrm{NH}_{3}{ }^{+}+$ $\mathrm{NO}_{3}{ }^{-} \rightarrow \mathrm{CH}_{3} \mathrm{NH}_{2}+\mathrm{HNO}_{3}$ will occur frequently. Thus, it is reasonable to expect the generation of $\mathrm{HNO}_{3}$ both from $\mathrm{ADN}$ decomposition and from proton transfer in the ADN/MMAN mixture. On this basis, we conclude that the peak at $m / z 45.99$ is actually derived from $\mathrm{HNO}_{3}$, not $\mathrm{NO}_{2}$. Although $\mathrm{NO}_{2}$ will also appear at $\mathrm{m} / z=45.99\left(\mathrm{NO}_{2}{ }^{+}\right)$and is an important product of ADN decomposition, if the $m / z 45.99$ peak in Figure 1(b) is attributed to $\mathrm{NO}_{2}$, the peak at $\mathrm{m} / z 29.99$ should be approximately three times more intense. This is because the majority of $\mathrm{NO}_{2}$ breaks into $\mathrm{NO}^{+}$and $\mathrm{O}^{+}$during ionization in the MS, such that the quantity of $\mathrm{NO}^{+}(m / z 29.99)$ will be greater than that of $\mathrm{NO}_{2}^{+}(\mathrm{m} / z$ 45.99) at an acceleration energy of $70 \mathrm{eV}$. However, the $m / z 30$ 
peak height is much less than three times that of the $m / z 45.99$ peak height in Figure 1(b). In addition, only a very weak peak at $m / z 46$, ascribed to $\mathrm{NO}_{2}{ }^{+}$, was detected in a previous TGDSC-MS study of pure ADN decomposition [23]. The $\mathrm{NO}_{2}$ generated from ADN decomposition appears to immediately react with liquid phase species, such that the quantity of $\mathrm{NO}_{2}$ evolved is negligible compared to that of $\mathrm{HNO}_{3}$

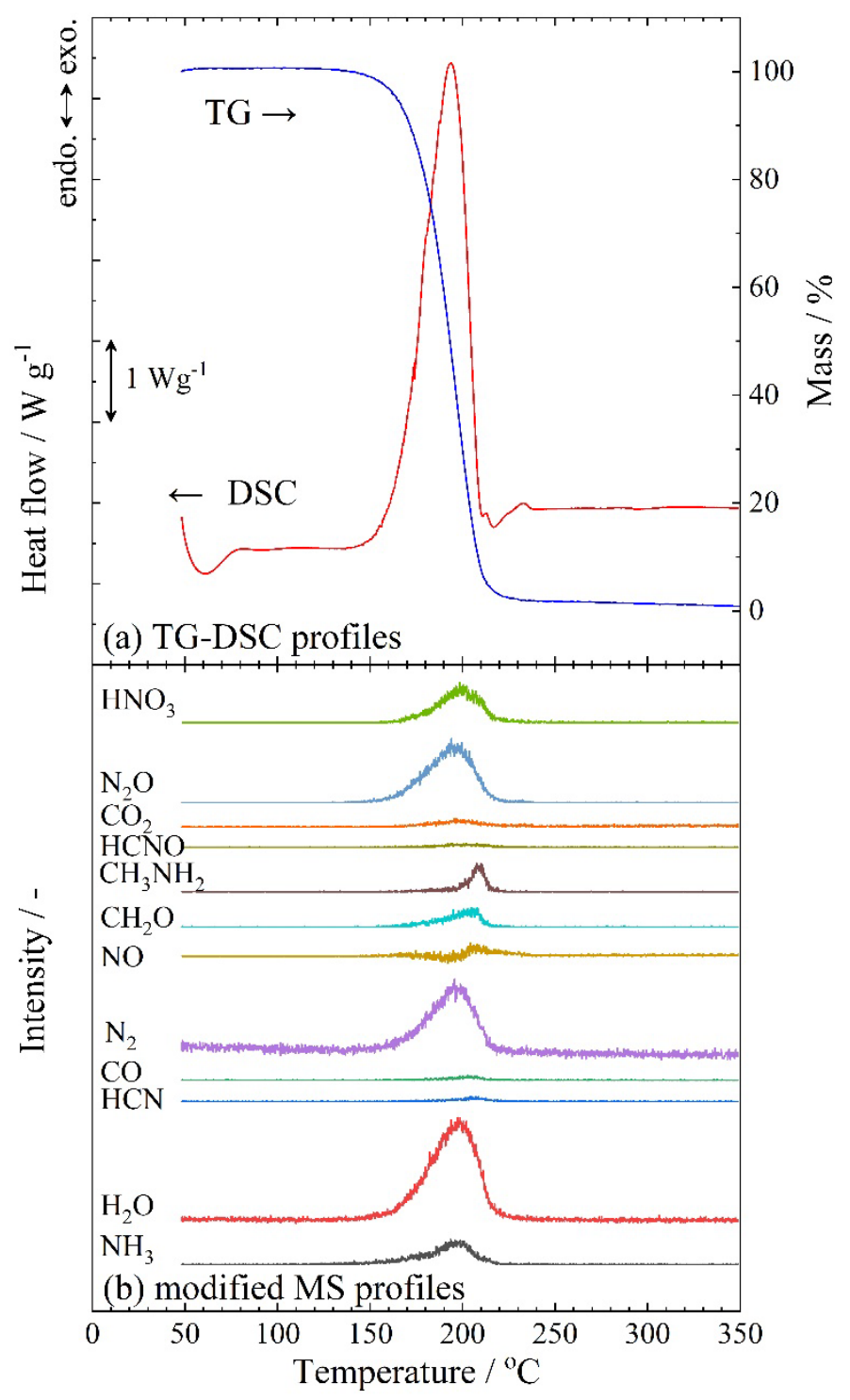

Figure 2. Thermal and evolving gas behavior of ADN/MMAN at $10 \mathrm{~K} \mathrm{~min}^{-1}$.

Figure 2 summarizes the thermal behavior and the major gas species generated by the ADN/MMAN mixture, based on TG-DSC-HRTOFMS data. The gas intensity plots were obtained by summing the intensities of the mass fragments of the different gases. As an example, the intensity at $m / z 30\left(\mathrm{NO}^{+}\right)$was made by combining fragments from $\mathrm{NO}, \mathrm{HNO}_{3}$, and $\mathrm{N}_{2} \mathrm{O}$. To obtain the true intensities of the various gases, the apparent intensities of the fragments must be adjusted by summing related peaks and subtracting overlapping unrelated peaks. This was performed based on the known ratios of various mass fragments in a previously published database [32] as well as prior data for $\mathrm{HNO}_{3}$ [33]. The associated calculations and respective gas intensities are presented below as equations 1 through 11.

$$
\begin{aligned}
& I_{\mathrm{HNO}_{3}}^{\text {total }} \cong I_{\mathrm{NO}_{2}^{+}\left(\mathrm{HNO}_{3}^{+}\right)}^{46}+I_{\mathrm{NO}^{+}\left(\mathrm{HNO}_{3}^{+}\right)}^{30}=I_{\mathrm{NO}_{2}^{+}}^{46}+\frac{85.7}{100} I_{\mathrm{NO}_{2}^{+}}^{46}(1) \\
& I_{\mathrm{N}_{2} \mathrm{O}}^{\text {total }} \cong I_{\mathrm{N}_{2} \mathrm{O}^{+}}^{44}+I_{\mathrm{NO}^{+}\left(\mathrm{N}_{2} \mathrm{O}^{+}\right)}^{30}+I_{\mathrm{N}_{2}^{+}\left(\mathrm{N}_{2} \mathrm{O}^{+}\right)}^{28}=I_{\mathrm{N}_{2} \mathrm{O}^{+}}^{44}+\frac{3113}{9999} I_{\mathrm{N}_{2} \mathrm{O}^{+}}^{44}+\frac{1008}{9999} I_{\mathrm{N}_{2} \mathrm{O}^{+}}^{44}
\end{aligned}
$$




$$
\begin{aligned}
& I_{\mathrm{CO}_{2}}^{\text {total }} \cong I_{\mathrm{CO}_{2}^{+}}^{44}+I_{\mathrm{CO}^{+}\left(\mathrm{CO}_{2}^{+}\right)}^{28}=I_{\mathrm{CO}_{2}^{+}}^{44}+\frac{981}{9999} I_{\mathrm{CO}_{2}^{+}}^{44}(3) \\
& I_{\mathrm{HCNO}}^{\text {total }} \cong I_{\mathrm{HCNO}^{+}}^{43}+I_{\mathrm{CNO}^{+}\left(\mathrm{HCNO}^{+}\right)}^{26}+I_{\mathrm{HCO}^{+}\left(\mathrm{HCNO}^{+}\right)}^{26}=I_{\mathrm{HCN}^{+}}^{27}+\frac{20}{100} I_{\mathrm{HCN}^{+}}^{27}+\frac{32}{100} I_{\mathrm{HCN}^{+}}^{27} \\
& I_{\mathrm{CH}_{3} \mathrm{NH}_{2}}^{\text {total }} \cong I_{\mathrm{CH}_{3} \mathrm{NH}_{2}^{+}}^{31}+I_{\mathrm{CH}_{3} \mathrm{NH}^{+}\left(\mathrm{CH}_{3} \mathrm{NH}_{2}^{+}\right)}^{30}+I_{\mathrm{CH}_{2} \mathrm{NH}^{+}\left(\mathrm{CH}_{3} \mathrm{NH}_{2}^{+}\right)}^{29}+I_{\mathrm{CH}_{2} \mathrm{~N}^{+}\left(\mathrm{CH}_{3} \mathrm{NH}_{2}^{+}\right)}^{28} \\
& \quad=I_{\mathrm{CH}_{3} \mathrm{NH}_{2}^{+}}^{31}+\frac{9999}{6559} I_{\mathrm{CH}_{3} \mathrm{NH}_{2}^{+}}^{31}+\frac{1239}{6559} I_{\mathrm{CH}_{3} \mathrm{NH}_{2}^{+}}^{31}+\frac{5389}{6559} I_{\mathrm{CH}_{3} \mathrm{NH}_{2}^{+}}^{31}(5) \\
& I_{\mathrm{NO}}^{\text {total }} \cong I_{\mathrm{NO}^{+}}^{30}-I_{\mathrm{NO}^{+}\left(\mathrm{N}_{2} \mathrm{O}^{+}\right)}^{30}=I_{\mathrm{NO}^{+}}^{30}-\frac{3113}{9999} I_{\mathrm{N}_{2} \mathrm{O}}^{44}-\frac{85.7}{100} I_{\mathrm{NO}_{2}^{+}}^{46} \quad(6) \\
& I_{\mathrm{N}_{2}}^{\text {total }} \cong I_{\mathrm{N}_{2}^{+}}^{28}-I_{\mathrm{N}_{2}^{+}\left(\mathrm{N}_{2} \mathrm{O}^{+}\right)}^{28}+\frac{1}{2} I_{\mathrm{N}^{+}}^{14}=I_{\mathrm{N}_{2}^{+}}^{28}-\frac{1008}{9999} I_{\mathrm{N}_{2} \mathrm{O}^{+}}^{44}+\frac{1}{2} \frac{1379}{9999}\left(I_{\mathrm{N}_{2}^{+}}^{28}-\frac{1008}{9999} I_{\mathrm{N}_{2} \mathrm{O}^{+}}^{44}\right) \\
& I_{\mathrm{CO}}^{\text {total }} \cong I_{\mathrm{CO}^{+}}^{28}-I_{\mathrm{CO}^{+}\left(\mathrm{CO}_{2}^{+}\right)}^{28}=I_{\mathrm{CO}^{+}}^{28}-\frac{981}{9999} I_{\mathrm{CO}_{2}^{+}}^{44}(8) \\
& I_{\mathrm{HCN}}^{\text {total }} \cong I_{\mathrm{HCN}^{+}}^{27}-I_{\mathrm{CN}^{+}\left(\mathrm{HCN}^{+}\right)}^{276}=I_{\mathrm{HCN}^{+}}^{27}-\frac{1682}{9999} I_{\mathrm{CN}^{+}\left(\mathrm{HCN}^{+}\right)}^{26}(9) \\
& I_{\mathrm{H}_{2} \mathrm{O}}^{\text {total }} \cong I_{\mathrm{H}_{2} \mathrm{O}^{+}}^{18}+I_{\mathrm{OH}^{+}\left(\mathrm{H}_{2} \mathrm{O}^{+}\right)}^{17}=I_{\mathrm{H}_{2} \mathrm{O}^{+}}^{18}+\frac{2122}{9999} I_{\mathrm{H}_{2} \mathrm{O}^{+}}^{18}(10) \\
& I_{\mathrm{NH}}^{\text {total }} \cong I_{\mathrm{NH}_{3}^{+}}^{17}+I_{\mathrm{NH}_{2}^{+}\left(\mathrm{NH}_{3}^{+}\right)}^{16}=I_{\mathrm{NH}_{3}^{+}}^{17}+\frac{8007}{9999} I_{\mathrm{NH}_{3}^{+}}^{17}(11)
\end{aligned}
$$

Here, $I_{i(f)}^{n}$ is the relative intensity of ionized gas $i$ or ion fragment $i$, having $m / z=n$ and related to species $f$. Using these calculations, the relative intensity plots in Figure 2 were obtained from the MS data in Figure 1.

To assist in evaluating the ADN/MMAN mixture, the gases evolved from pure ADN decomposition and the associated reaction scheme are shown below. The major decomposition products obtained from pure $\mathrm{ADN}$ are known to be $\mathrm{N}_{2} \mathrm{O}$ and ammonium nitrate $\left(\mathrm{NH}_{4} \mathrm{NO}_{3}\right)$, followed by $\mathrm{NH}_{4} \mathrm{NO}_{3}$ pyrolysis to form $\mathrm{N}_{2} \mathrm{O}$ and water according to Scheme 1 [34].

Scheme 1 .

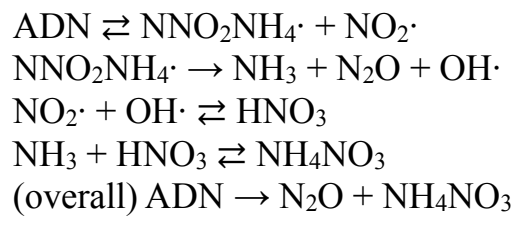

$\mathrm{NH}_{4} \mathrm{NO}_{3} \rightarrow \mathrm{N}_{2} \mathrm{O}+2 \mathrm{H}_{2} \mathrm{O}$

ADN decomposition also produces $\mathrm{N}_{2}$ via minor side reactions, initiated by the reaction $\mathrm{NH}_{3}$ $+\mathrm{OH} \cdot \rightarrow \mathrm{NH}_{2} \cdot+\mathrm{H}_{2} \mathrm{O}$. In this pathway, $\mathrm{NH}_{2}$ bonds to $\mathrm{NO}_{2}$. to yield nitramide $\left(\mathrm{NH}_{2} \mathrm{NO}_{2}\right)$ or $\mathrm{NH}_{2} \mathrm{ONO}$, after which the $\mathrm{NH}_{2} \mathrm{NO}_{2}$ decomposes to $\mathrm{N}_{2} \mathrm{O}$ and $\mathrm{H}_{2} \mathrm{O}$ [35] while the $\mathrm{NH}_{2} \mathrm{ONO}$ decomposes to $\mathrm{NH}_{2} \mathrm{O}$. and $\mathrm{NO} \cdot$ via homolytic cleavage of the $\mathrm{NH}_{2} \mathrm{O}-\mathrm{NO}$ bond. Following the reaction of the $\mathrm{NO}$ and $\mathrm{NH}_{2} \cdot$ radicals, the resulting $\mathrm{NH}_{2} \mathrm{NO}$ decomposes to produce $\mathrm{N}_{2}$ and $\mathrm{H}_{2} \mathrm{O}$ via $\mathrm{NHNOH}$. Thus, the evolved gases obtained from pure ADN include $\mathrm{N}_{2} \mathrm{O}, \mathrm{H}_{2} \mathrm{O}$ and a lesser amount of $\mathrm{N}_{2}$. In addition, the $\mathrm{HONO}$-catalyzed decomposition of $\mathrm{HNO}_{3}$ can occur to produce $\mathrm{N}_{2}$, based on the reaction of $\mathrm{HONO}$ with $\mathrm{HNO}_{3}$, with a low energy barrier, to produce highly reactive trans- $\mathrm{ONONO}_{2}[36,37]$. These reactions are summarized in Scheme 2.

Scheme 2 .

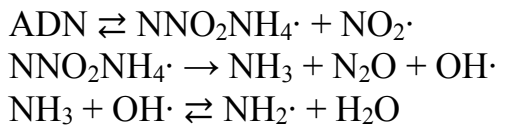




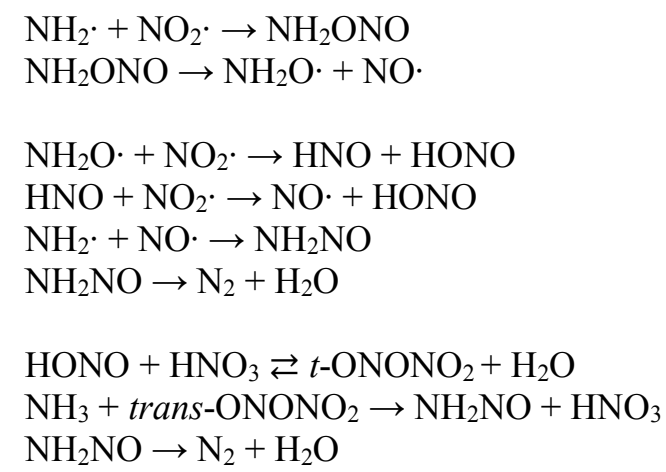

As shown in Figure 2, a significant amount of $\mathrm{N}_{2}$, which is a minor product of pure ADN decomposition, was evolved during ADN/MMAN decomposition. The production of large quantities of $\mathrm{N}_{2}$, which is non-toxic and has a low molecular weight, is a desirable characteristic for a propellant, and so it is important to consider the $\mathrm{N}_{2}$ evolution mechanism. One possible origin is as an MMAN decomposition product. The major products of MMAN degradation at $200{ }^{\circ} \mathrm{C}$ are reported to be $\mathrm{H}_{2} \mathrm{O}, \mathrm{NO}_{2}, \mathrm{NO}$ and $\mathrm{N}_{2}$ [38]. However, the onset temperature of the exothermic reaction of pure MMAN is approximately $260{ }^{\circ} \mathrm{C}$ under non-isothermal heating conditions [38, 39], which is much higher than the onset temperature observed in Figure 2. In the case of the exothermic reaction evident in this figure, the interaction between the ADN and MMAN may enhance $\mathrm{N}_{2}$ generation, and two possible schemes were developed based on the evolved gas analysis. In one scenario, the MMAN enhances the mechanism shown in Scheme 2. The ADN/MMAN mixture produces a considerable amount of $\mathrm{HNO}_{3}$ due to proton transfer via the equilibrium reaction MMAN $\rightleftarrows \mathrm{CH}_{3} \mathrm{NH}_{2}+\mathrm{HNO}_{3}$, and the $\mathrm{HNO}_{3}$ thus generated shifts the equilibrium of the reaction $\mathrm{NO}_{2} \cdot+\mathrm{OH} \cdot \rightleftarrows \mathrm{HNO}_{3}$ to left. As a result, Scheme 2 is enhanced.

The second possibility is a reaction between ADN and MMAN, as shown in Scheme 3.

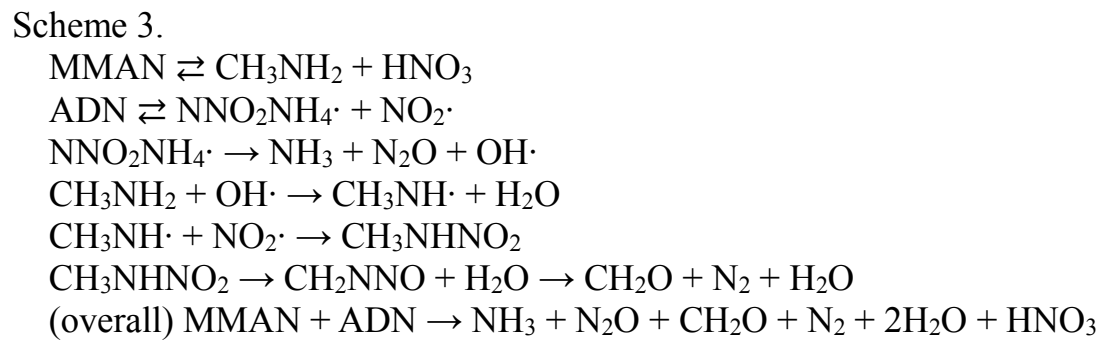

This mechanism was generated by adding the $\mathrm{H}$-abstraction of $\mathrm{CH}_{3} \mathrm{NH}_{2}$ and the following reactions to Scheme 2. In Scheme 2, the radicals obtained from $\mathrm{ADN}\left(\mathrm{OH} \cdot\right.$ and $\left.\mathrm{NO}_{2} \cdot\right)$ attack only $\mathrm{NH}_{3}$, whereas in the ADN/MMAN system, these species can also attack $\mathrm{CH}_{3} \mathrm{NH}_{2}$. The $\mathrm{OH} \cdot$ reacts with $\mathrm{CH}_{3} \mathrm{NH}_{2}$ to form $\mathrm{CH}_{3} \mathrm{NH}$, after which the $\mathrm{CH}_{3} \mathrm{NH}$. bonds to $\mathrm{NO}_{2}$. to yield $\mathrm{CH}_{3} \mathrm{NHNO}_{2}$. This product subsequently decomposes to $\mathrm{CH}_{2} \mathrm{NNO}$ and $\mathrm{H}_{2} \mathrm{O}$ via an intramolecular proton transfer, and the resulting $\mathrm{CH}_{2} \mathrm{NNO}$ decomposes to $\mathrm{N}_{2}$ and $\mathrm{CH}_{2} \mathrm{O}$ via cleavage of the $\mathrm{CH}_{2}-\mathrm{NN}-\mathrm{O}$ bonds and reformation of the $\mathrm{CH}_{2}-\mathrm{O}$ bond. A reasonable quantity of $\mathrm{CH}_{2} \mathrm{O}$ was detected by TG-DSC-HRTOFMS, as shown in Figure 2(b), and so our results support the proposed reaction scheme. However, this mechanism indicates that equal molar amounts of $\mathrm{CH}_{2} \mathrm{O}, \mathrm{NH}_{3}$ and $\mathrm{N}_{2}$ should be obtained, such that the $\mathrm{CH}_{2} \mathrm{O}$ and $\mathrm{NH}_{3}$ peak intensities should be similar to that of $\mathrm{N}_{2}$, assuming equal ionization efficiencies. However, the $\mathrm{CH}_{2} \mathrm{O}$ and $\mathrm{NH}_{3}$ peaks were less intense than that of $\mathrm{N}_{2}$, suggesting that both Schemes 2 and 3 occur simultaneously during the exothermic reaction.

Figure 2(b) also demonstrates the production of a minimal amount of $\mathrm{CO}_{2}$ from the ADN/MMAN compared with the amounts of $\mathrm{N}_{2}$ and $\mathrm{N}_{2} \mathrm{O}$. ADN does not contain carbon atoms, whereas MMAN has one carbon atom in each molecule. If this carbon is completely oxidized by the $\mathrm{ADN}$, which is a strong oxidizer, a considerable quantity of $\mathrm{CO}_{2}$ should be contained in the decomposition gases. The TG-DSC-HRTOFMS data suggest that the carbon in the MMAN was captured in $\mathrm{CH}_{2} \mathrm{O}$ (as in Scheme 3) or remained in $\mathrm{CH}_{3} \mathrm{NH}_{2}$ dissociated from the MMAN, without the occurrence of any additional chemical reactions. Considering the potential use of $\mathrm{ADN} / \mathrm{MMAN}$ as a propellant, significant $\mathrm{N}_{2}$ generation is desirable, while the presence of unburned carbon is not. Completely oxidizing the unreacted carbon from the MMAN would 
provide a greater energy release and also improve the ignitability of the propellant. Thus, further research regarding suitable catalysts and methods to obtain complete $\mathrm{CH}_{3} \mathrm{NH}_{2}$ combustion is needed.

\section{ADN/MMAN/Urea}

Figure 3 shows the TG-DSC-HRTOFMS results for the ADN/MMAN/urea mixture. The TGDSC data (Figure 3(a)) indicate an exothermic event associated with mass loss over the range of approximately $140-200{ }^{\circ} \mathrm{C}$, along with an endothermic event that is also associated with mass loss at approximately $200-260{ }^{\circ} \mathrm{C}$. The heat values for these two reactions were determined to be $634 \pm 13 \mathrm{~J} \mathrm{~g}^{-1}$ and $-220 \pm 8 \mathrm{~J} \mathrm{~g}^{-1}$, respectively. Comparing the data obtained using ADN/MMAN, the addition of urea evidently reduces the exothermic heat of reaction in addition to inducing the subsequent endothermic reaction. The maximum heat flow obtained from the ADN/MMAN/urea (approximately $3.0 \mathrm{~W} \mathrm{~g}^{-1}$ ) is also lower than that obtained from the ADN/MMAN $\left(6.0 \mathrm{~W} \mathrm{~g}^{-1}\right)$. Pure urea exhibits an endothermic peak associated with melting and decomposition at approximately $133{ }^{\circ} \mathrm{C}[40,41]$, and this reaction appears to offset the exothermic reaction of the ADN/MMAN mixture. Approximately $1 \%$ of the original mass remained at $350{ }^{\circ} \mathrm{C}$, as was also the case for the ADN/MMAN, demonstrating that the $\mathrm{ADN} / \mathrm{MMAN} /$ urea also produced some solid residue over this temperature range.

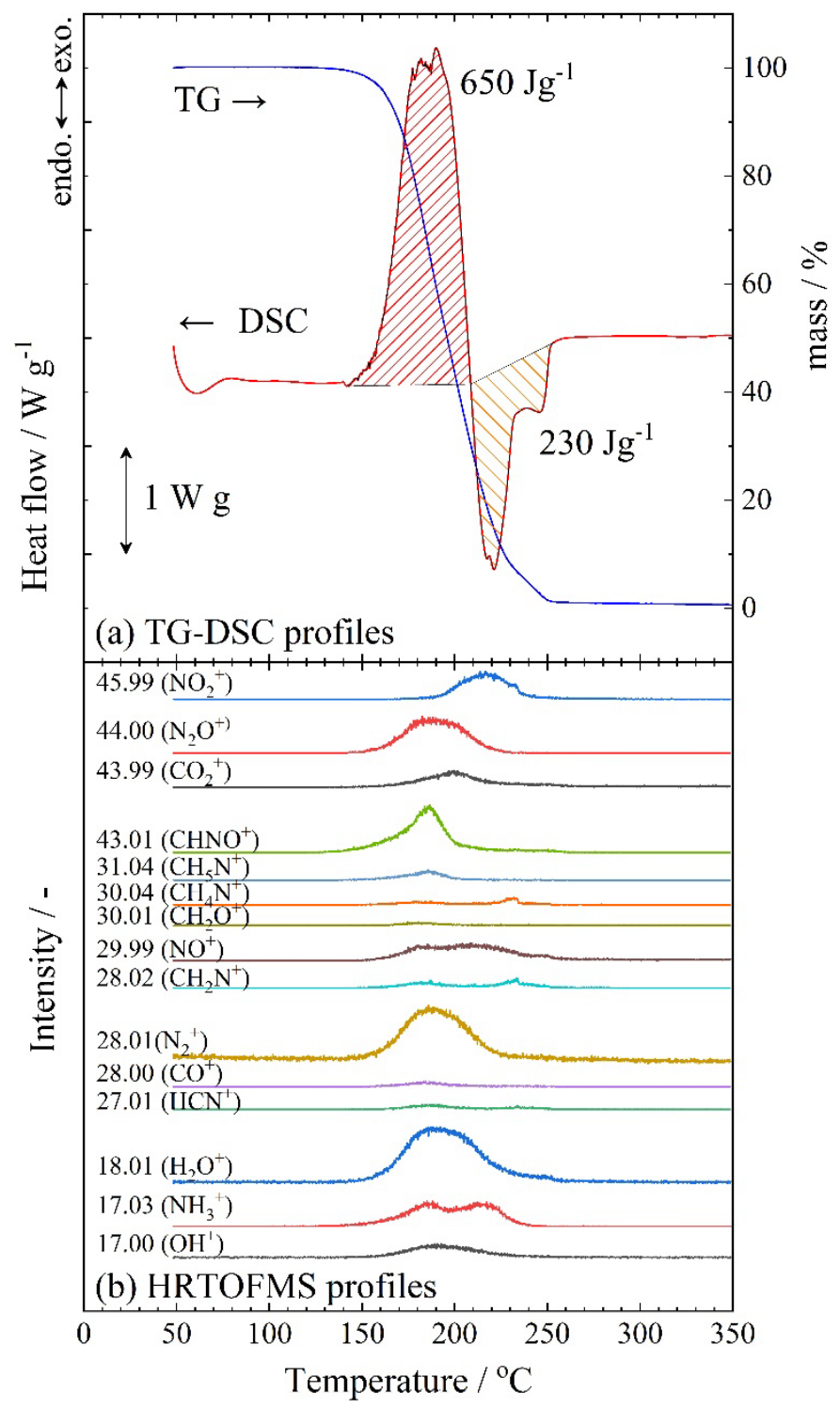

Figure 3. TG-DSC-HRTOFMS results for ADN/MMAN/urea at a heating rate of $10{ }^{\circ} \mathrm{C} \mathrm{min}^{-1}$. 
The MS analysis of the ADN/MMAN/urea shows peaks at $m / z$ values of $17.00\left(\mathrm{OH}^{+}\right), 17.03$ $\left(\mathrm{NH}_{3}^{+}\right), 18.01\left(\mathrm{H}_{2} \mathrm{O}^{+}\right), 27.01\left(\mathrm{HCN}^{+}\right), 28.00\left(\mathrm{CO}^{+}\right), 2801\left(\mathrm{~N}_{2}^{+}\right), 28.02\left(\mathrm{CH}_{2} \mathrm{~N}^{+}\right), 29.99\left(\mathrm{NO}^{+}\right)$, $30.01\left(\mathrm{CH}_{2} \mathrm{O}^{+}\right), 30.04\left(\mathrm{CH}_{4} \mathrm{~N}^{+}\right), 31.04\left(\mathrm{CH}_{5} \mathrm{~N}^{+}\right), 43.01\left(\mathrm{CHNO}^{+}\right), 43.99\left(\mathrm{CO}_{2}{ }^{+}\right), 44.00\left(\mathrm{~N}_{2} \mathrm{O}^{+}\right)$ and $45.99\left(\mathrm{NO}_{2}{ }^{+}\right)$, and the associated temperature change profiles are presented in Figure 3(b) while those of other minor species are provided in the Supplementary Materials. From these results, the major evolved gases were determined to be $\mathrm{NH}_{3}, \mathrm{H}_{2} \mathrm{O}, \mathrm{HCN}, \mathrm{CO}, \mathrm{N}_{2}, \mathrm{CH}_{2} \mathrm{O}$, $\mathrm{CH}_{3} \mathrm{NH}_{2}, \mathrm{HNCO}, \mathrm{CO}_{2}, \mathrm{~N}_{2} \mathrm{O}$ and $\mathrm{HNO}_{3}$. Figure 4 summarizes the thermal behavior and product generation profiles obtained from the TG-DSC-HRTOFMS data, taking into account the mass fragment values and equations (1) to (11).

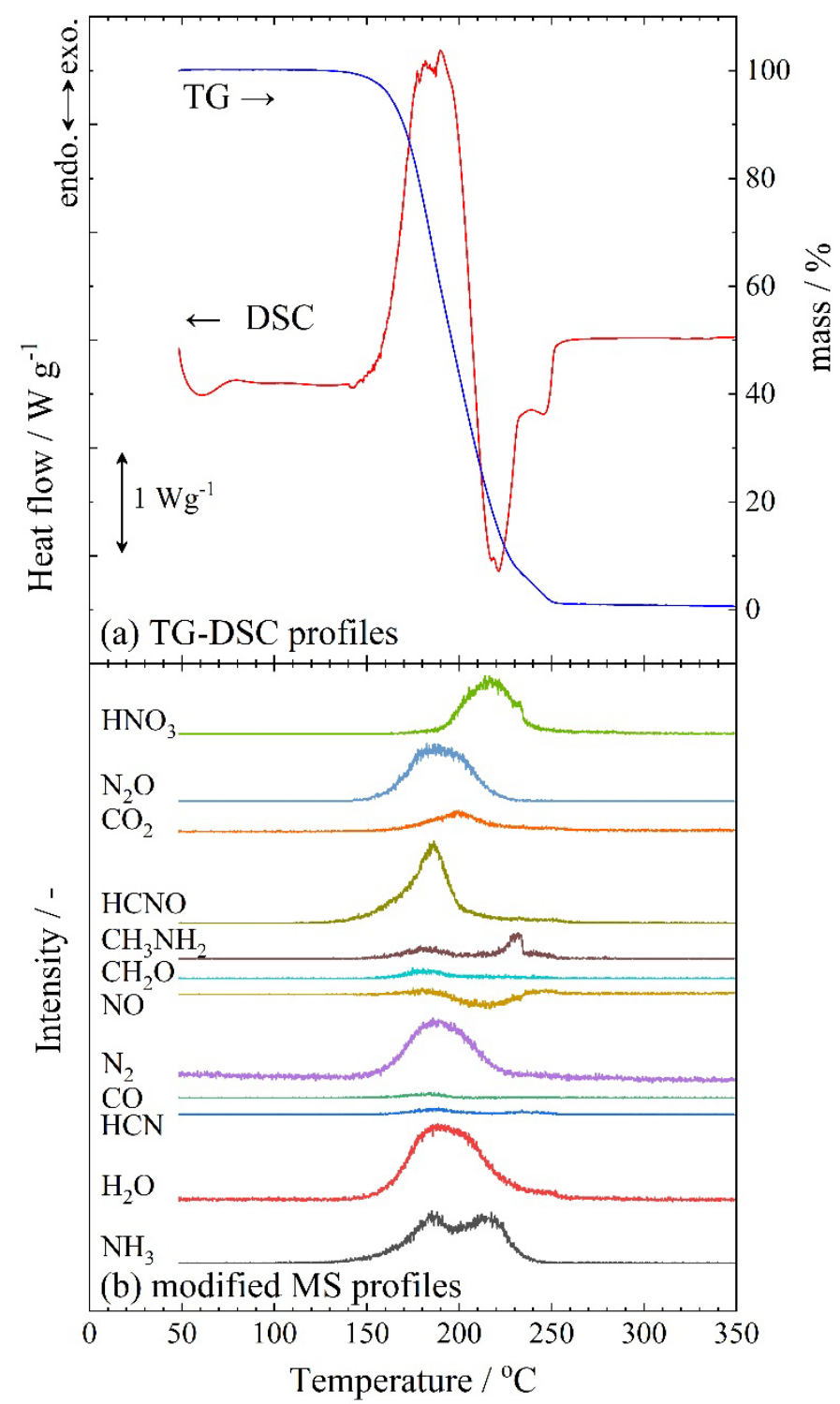

Figure 4. Thermal and gas evolution behavior of ADN/MMAN/urea at $10{ }^{\circ} \mathrm{C} \mathrm{min}{ }^{-1}$.

The ADN/MMAN/urea ternary mixture is distinguished by the formation of $\mathrm{HNCO}$ and $\mathrm{CO}_{2}$ as decomposition products. These are both derived from the decomposition of urea, based on the following endothermic reactions [40, 41].

\section{Scheme 4.}

$\left(\mathrm{NH}_{2}\right)_{2} \mathrm{CO}$ (Urea) $\rightarrow \mathrm{NH}_{3}+\mathrm{HNCO}$

$\mathrm{HNCO}+\mathrm{H}_{2} \mathrm{O} \rightarrow \mathrm{NH}_{3}+\mathrm{CO}_{2}$

The endothermic peak associated with pure urea decomposition appears at approximately $133{ }^{\circ} \mathrm{C}[40,41]$, which matches the onset temperature for the evolution of $\mathrm{HNCO}$ and $\mathrm{NH}_{3}$ in Figure 4(b). In the case of pure urea, the $\mathrm{HNCO}$ reacts with $\mathrm{H}_{2} \mathrm{O}$ to form $\mathrm{NH}_{3}$ and $\mathrm{CO}_{2}$ and this 
same reaction appears to occur in the ADN/MMAN/urea mixture. As shown in Figure 4, $\mathrm{CO}_{2}$ is produced following the generation of $\mathrm{HNCO}$, and there is a second formation of $\mathrm{NH}_{3}$ associated with the endothermic reaction due to the reaction $\mathrm{HNCO}+\mathrm{H}_{2} \mathrm{O} \rightarrow \mathrm{NH}_{3}+\mathrm{CO}_{2}$.

The second endothermic peak over the range of $200-260^{\circ} \mathrm{C}$ is associated with the generation of $\mathrm{NH}_{3}, \mathrm{CH}_{3} \mathrm{NH}_{2}$ and $\mathrm{HNO}_{3}$. These products may stem from the endothermic dissociation of $\mathrm{NH}_{4} \mathrm{NO}_{3}$ to $\mathrm{NH}_{3}+\mathrm{HNO}_{3}$ (as also occurs during the decomposition of pure ADN) and of MMAN to $\mathrm{CH}_{3} \mathrm{NH}_{2}+\mathrm{HNO}_{3}$. These results indicate that unreacted MMAN and the intermediate ammonium nitrate both exist over the range of $200-260^{\circ} \mathrm{C}$, and that urea inhibits the interaction between ADN and MMAN.

Considering the potential use of ADN/MMAN/urea as a propellant, the addition of urea is evidently an effective means of decreasing the melting point of the mixture [5]. However, the present TG-DSC-HRTOFMS results demonstrate that urea does not promote the decomposition of ADN/MMAN, while its decomposition decreases the net heat release from the exothermic reaction. The endothermic reaction of urea would also be expected to negatively affect the ignitability of an ADN-based propellant, which represents a major impediment to the use of this ionic liquid in spacecraft. The ignition properties of this material could potentially be improved by replacing urea with other more suitable materials.

\section{Conclusions}

This work analyzed the heat flow, mass loss and gas evolution occurring during the thermal decomposition of ionic liquid propellants with ADN/MMAN and ADN/MMAN/urea formulations, based on TG-DSC-HRTOFMS data. The following conclusions can be drawn.

1) TA-EGA using TG-DSC-HRTOFMS is a useful means of investigating the reaction mechanisms of energetic materials. The simultaneous acquisition of thermal and MS data can be used to determine the thermal behavior of ionic liquid propellant samples and to accurately identify the gases evolved upon heating.

2) ADN/MMAN decomposition involves an exothermic event associated with a mass loss at approximately $130-210^{\circ} \mathrm{C}$ when using a heating rate of $10^{\circ} \mathrm{C} \mathrm{min}^{-1}$. The heat release accompanying this reaction was determined to be $1057 \pm 94 \mathrm{~J} \mathrm{~g}^{-1}$. The major evolved gases were $\mathrm{NH}_{3}, \mathrm{H}_{2} \mathrm{O}, \mathrm{HCN}, \mathrm{N}_{2}, \mathrm{CH}_{2} \mathrm{O}, \mathrm{CH}_{3} \mathrm{NH}_{2}, \mathrm{~N}_{2} \mathrm{O}$ and $\mathrm{HNO}_{3}$. A possible ADN/MMAN decomposition process was proposed based on the evolved gas analysis, in which interactions between ADN and MMAN enhance the evolution of $\mathrm{N}_{2}$.

3) In the case of ADN/MMAN/urea, an exothermic event occurs (associated with a mass loss) at approximately $140-200{ }^{\circ} \mathrm{C}$, followed by an endothermic event (also associated with a mass loss) at approximately $200-260{ }^{\circ} \mathrm{C}$. The heat exchanges associated with the exothermic and endothermic reactions were determined to be $634 \pm 13 \mathrm{~J} \mathrm{~g}^{-1}$ and $220 \pm 8 \mathrm{~J}$ $\mathrm{g}^{-1}$, respectively. The ADN/MMAN/urea evolved $\mathrm{NH}_{3}, \mathrm{H}_{2} \mathrm{O}, \mathrm{N}_{2}, \mathrm{HCN}, \mathrm{CH}_{2} \mathrm{O}, \mathrm{CH}_{3} \mathrm{NH}_{2}$, $\mathrm{HNCO}, \mathrm{CO}_{2}, \mathrm{~N}_{2} \mathrm{O}$ and $\mathrm{HNO}_{3}$. Compared to the ADN/MMAN mixture, the production of $\mathrm{CO}_{2}$, $\mathrm{HNCO}$ and $\mathrm{NH}_{3}$ were characteristic of the formulation containing urea, due to the endothermic decomposition of the urea. Mixing urea into the ADN/MMAN lowers the net exothermic heat of reaction due to the endothermic pyrolysis of urea to give $\mathrm{NH}_{3}$ and $\mathrm{HNCO}$, followed by the reaction $\mathrm{HNCO}+\mathrm{H}_{2} \mathrm{O} \rightarrow \mathrm{NH}_{3}+\mathrm{CO}_{2}$.

4) The application of $\mathrm{ADN} / \mathrm{MMAN}$ or $\mathrm{ADN} / \mathrm{MMAN} / \mathrm{urea}$ mixtures as propellants will require the complete oxidation of the unburned carbon in MMAN and the identification of an alternate to urea, so as to improve the energy release during decomposition and the ignitability of the propellant.

Acknowledgement

This research was supported by JSPS KAKENHI Grant Number $17 \mathrm{H} 00844$.

Reference

1. Larsson A, Wingborg N. Green Propellants Based on Ammonium Dinitramide (ADN). In: Hall J editor. Advances in Spacecraft Technologies, InTech; 2011. pp.139-156.

2. Nagamachi MY, Oliveira JI, Kawamoto AM, Dutra RCL. ADN- The new oxidizer aroudthe corner for an environmentally friendly smokeless propellant. J Aerosp Technol Manage. 2009; $1: 153-160$. 
3. Östmark H, Bemm U, Langlet A, Sanden R. Wingborg N. The properties of ammonium dinitramide $(\mathrm{ADN})$ : part 1, basic properties and spectroscopic data. J Energ Mater. 2000;18:123-8.

4. Negri M, Wilhelm M, Hendrich C, Wingborg N, Gediminas L, Adelöw L, Maleix C, Chabernaud P, Brahmi R, Beauchet R, Batonneau Y, Kappenstein C, Koopmans R-J, Schuh S, Bartok T, Scharlemann C, Gotzig U, Schwentenwein M. New technologies for ammonium dinitramide based monopropellant thrusters - The project RHEFORM. Acta Astronaut. 2018;143:105-117.

5. Shiota K, Itakura M, Izato Y, Matsunaga H, Habu H, Miyake A. Effects of amide compounds and nitrate salts on the melting point depression of ammonium dinitramide. Sci Technol Energ Mater. 2018;79:137-141.

6. Matsunaga H, Habu H, Miyake A. Preparation and thermal decomposition behavior of ammonium dinitramide-based energetic ionic liquid propellant. Sci Technol Energ Mater. 2017;78:65-70.

7. Matsunaga H, Katoh K, Habu H, Noda M, Miyake A. preparation and thermal decomposition behavior of high-energy ionic liquids based on ammonium dinitramide and amine nitrates. Trans JSASS Aerospace Tech Japan. 2018;16:82-92.

8. Matsunaga H, Habu H, Miyake A. Thermal decomposition mechanism of ammonium dinitramide. New Trends Res. Energ. Mater., Proc. Semin. 16th. 2013;268-276.

9. Matsunaga H, Katoh K, Habu H, Noda M, Miyake A. Thermal behavior of ammonium dinitramide and amine nitrate mixtures. J Therm Anal Calorim. 2019;135:2677-2685.

10. Ide Y, Takahashi T, Iwai K, Nozoe K, Habu H, Tokudome S. Potential of ADN-based ionic liquid propellant for spacecraft propulsion. Procedia Eng. 2015;99:332-337.

11. Izato Y, Miyake A. Kinetic analysis of the thermal decomposition of liquid ammonium nitrate based on thermal analysis and detailed reaction simulations. J Therm Anal Calorim. 2018; 134:813-823.

12. Izato Y, Miyake A. Detailed kinetic model for ammonium dinitramide decomposition. Combust Flame. 2018;198:222-229.

13. Zhang K, Thynell ST. Thermal decomposition mechanism of aqueous hydroxylammonium nitrate (HAN): molecular simulation and kinetic modeling. J Phys Chem A. 2018;122:80868100.

14. Kumbhakarna N, Thynell ST. Development of a reaction mechanism for liquid-phase decomposition of guanidinium 5-amino tetrazolate. Thermochim Acta. 2014;582:25-34.

15. Ashcraft RW, Raman S, Green WH. Ab initio aqueous thermochemistry: application to the oxidation of hydroxylamine in nitric acid solution. J Phys Chem B. 2007;111: 11968-11983.

16. Zhu Y-L, Shan M-X, Xiao Z-X, Wang J-S, Jiao Q-J. Kinetics of thermal decomposition of $\varepsilon$ hexanitrohexaazaisowurtzitane by TG-DSC-MS-FTIR. Korean J Chem Eng. 2015;32:11641169.

17. Rejitha KS, Ichikawa $\mathrm{T}$, Mathew $\mathrm{S}$, Investigations on the thermal behaviour of [Ni(NH3)6](NO3)2 and [Ni(en)3](NO3)2 using TG-MS and TR-XRD under inert condition. J Therm Anal Calorim. 2012;107:887-892.

18. Kajiyama K, Izato Y, Miyake A. Thermal characteristics of ammonium nitrate, carbon, and copper(II) oxide mixtures. J Therm Anal Calorim. 2013;113:1475-1480.

19. Inoue C, Izato Y, Miyake A, Villermaux E. Direct self-sustained fragmentation cascade of reactive droplets. Phys Rev Lett. 2017;118:074502.

20. Sankaranarayanan A, Mallick L, Kumbhakarna NR. A numerical and experimental study of the decomposition pathways of guanidium nitrate. J Therm Anal Calorim. 2018;131:427-441.

21. Santhosh G, Soumyamol PB, Sreejith M, Reshmi S. Isoconversional approach for the nonisothermal decompositionkinetics of guanylurea dinitramide (GUDN). Thermochimica Acta. 2016;632:46-51.

22. Yoshino S, Miyake A. Thermal decomposition properties of 1,2,4-triazole-3-one and guanidine nitrate mixtures. J Therm Anal Calorim. 2010;102:513-516.

23. Izato Y, Koshi M, Miyake A, Habu H. Kinetics analysis of thermal decomposition of ammonium dinitramide (ADN). J Therm Anal Calorim. 2017;127:255-264.

24. Matsunaga H, Izato Y, Habu H, Miyake A. Thermal decomposition characteristics of mixtures of ammonium dinitramide and copper (II) oxide. J Therm Anal Calorim. 2015;121:319-326.

25. Matsunaga $\mathrm{H}, \mathrm{Habu} H$, Miyake A. Analysis of evolved gases during the thermal decomposition of ammonium diniramide under pressure. Sci Technol Energ Mater. 2017;78:75-80.

26. Izato Y, Miyake A. Thermal decomposition mechanism of ammonium nitrate and potassium chloride mixtures. J Therm Anal Calorim. 2015;121:287-294.

27. Shiota K, Izato Y, Matsunaga H, Habu H, Miyake A. Thermal properties of ammonium dinitramide, monomethylamine nitrate and urea based ionic liquid gel propellants. Trans Jpn 
Soc Aeronaut Space Sci. 2018;16:93-97.

28. Nakashima M, Itaura T, Matsunaga H, Higashi E, Takagi S, Katoh K. A fundamental study on the thermal decomposition and combustion behaviors of guanidine nitrate and basic copper nitrate mixture. J Therm Anal Calorim. 2018;131:95-100.

29. Sivadas DL, Thomas D, Haseena MS, Jayalatha T, Krishnan1 GR, Jacob S, Rajeev R. Insight into the catalytic thermal decomposition mechanism of ammonium perchlorate. $\mathrm{J}$ Therm Anal Calorim. 2019 https://doi.org/10.1007/s10973-019-08209-5.

30. $\mathrm{Xu} \mathrm{Z,} \mathrm{Cheng} \mathrm{Jin-Hong,} \mathrm{Wang} \mathrm{Q,} \mathrm{Cheng} \mathrm{J,} \mathrm{Hu} \mathrm{X.} \mathrm{The} \mathrm{influence} \mathrm{of} \mathrm{dissociation} \mathrm{reaction} \mathrm{on}$ ammonium nitrate thermal decomposition reaction. J Therm Anal Calorim. 2019;136:14151424.

31. Zhao C, Chi Y, Peng Q, Yang F, Zhou J, Wang X, Yu K, Fan G, Sun J. A study on the comprehension of differences in specific kinetic energy of TKX-50 and HMX from the perspective of gas products. Phys Chem Chem Phys. 2019;21:6600-6605.

32. Linstrom PJ, Mallard WG. NIST Chemistry WebBook. NIST Standard Reference Database Number 69. Eds. National Institute of Standards and Technology. http://webbook.nist.gov. Accessed 30 Sep 42018.

33. Friedel RA, Shultz JL, Sharkey AG. Mass spectrum of nitric acid. Anal Chem. 1967;45:1128.

34. Izato Y, Miyake A. The decomposition pathways of ammonium dinitramide on the basis of ab initio calculations. J Energ Mater. 2018;36:302-315.

35. Izato Y, Koshi M, Miyake A. Identification of thermal decomposition products and reactions for liquid ammonium nitrate on the basis of $\mathrm{ab}$ initio calculation. Int J Chem Kinet. 2017;49:8399.

36. Izato Y, Koshi M, Miyake A. Decomposition pathways for aqueous hydroxylammonium nitrate solutions: a DFT study. Cent Eur J Energ Mater. 2017;14:888-916.

37. Izato Y, Miyake A, Identification of radical reactions and products for aqueous hydroxylamine nitrate (HAN) solution based on ab initio calculations. Sci Technol Energ Mater. 2018;79:108114.

38. Kurniadi W, Brower KR. A reinvestigation of the thermal decomposition of methylammonium nitrate. J Org Chem. 1994;59:5502-5505.

39. Breisacher P, Takimoto HH, Denault GC, Hicks WA, Simultaneous mass spectrometric differential thermal analyses of nitrate salts of monomethylhydrazine and methylamine. Combust Flame. 1970;14:397-404.

40. Schaber P, Colson J, Higgins S, Thielen D, Anspach B, Brauer J. Thermal decomposition (pyrolysis) of urea in an open reaction vessel. Thermochem Acta. 2004;424:131-142.

41. Brack W, Heine B, Birkhold F, Kruse M, Schoch G, Tischer S, Deutschmann O. Kinetic modeling of urea decomposition based on systematic thermogravimetric analyses of urea and its most important by-products. Chem Eng Sci. 2014;106:1-8. 